\title{
"Normal" acute phase response in systemic sclerosis
}

\author{
M CHELLINGSWORTH, D G I SCOTT, P A CROCKSON, P A BACON
}

\begin{abstract}
An Italian woman with classic active progressive systemic sclerosis had a normal serum concentration of $C$ reactive protein ( $<6 \mathrm{mg} / \mathrm{l}$ ). During an infection with Staphylococcus aureus, however, the concentration rose to 250 $\mathrm{mg} / \mathrm{l}$. This was unexpected, since in scleroderma the acute phase response to infection (a brisk rise in serum concentrations of various proteins, including $\mathbf{C}$ reactive) has been thought to be defective.

This patient is evidence that the acute phase response does occur in systemic sclerosis and that probably it is the nature of the primary disease that masks the response in some cases.
\end{abstract}

\section{Introduction}

A rise in serum concentrations of several proteins-for example, $C$ reactive protein, haptoglobin, and caeruloplasmin-is a normal response to inflammation, infection, or tissue necrosis. This is known as the acute phase response, and changes in the concentrations of these proteins are often used to monitor the activity of inflammatory conditions. $\mathrm{C}$ reactive protein has been shown to correlate with disease activity in rheumatoid arthritis, Crohn's disease, infections, and various other inflammatory

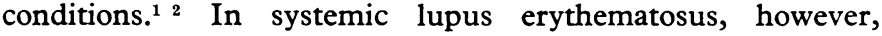
concentrations of $\mathrm{C}$ reactive protein are often only minimally raised, high values being restricted to patients whose disease is complicated by infection. ${ }^{3}$

Acute phase responses may also be induced experimentally. Infusions of prostaglandin $\mathrm{E}_{\mathbf{1}}$ produce a pronounced rise in $\mathrm{C}$ reactive protein within 24 hours in patients with arteriosclerotic vascular disease. In progressive systemic sclerosis, however, concentrations are normal or only marginally raised despite active disease and do not rise in response to prostaglandin $E_{1}$ infusion, suggesting that the patients have a defective acute phase response. ${ }^{4}$

We report a case of progressive systemic sclerosis in which there was a normal, brisk rise of $\mathrm{C}$ reactive protein in response to infection but low concentrations in active disease.

\section{Case report}

In 1975 a 41 year old Italian woman presented with typical progressive systemic sclerosis-sclerodactyly, proximal scleroderma, Raynaud's phenomenon, telangiectases, and arthralgia. Her history was uneventful apart from treated pulmonary tuberculosis in 1957. Early treatment included prednisolone $5 \mathrm{mg}$ daily and intermit-

\footnotetext{
Departments of Rheumatology and Investigative Pathology, Rheumatism Research Wing, University of Birmingham, Birmingham B15 2TJ

M CHELLINGSWORTH, BM, MRCP, senior house officer D G I SCOTT, MD, MRCP, lecturer

P A CROCKSON, FIMLS, senior chief medical laboratory scientific officer P A BACON, MB, FRCP, professor of rheumatology

Correspondence to: Professor P A Bacon.
}

tent penicillamine or colchicine. By 1981 new symptoms included painful ulcers on fingertips, joint contractures, angina pectoris, dyspnoea, dysphagia, and faecal incontinence. Examination showed generalised skin pigmentation and scleroderma affecting hands, forearms, face, and anterior chest wall. There was no history of alopecia, sensitivity to sun, mucosal ulceration, haematological abnormality, or myalgia.

Investigations disclosed antinuclear antibody (1/1000, nucleolar pattern) and the nuclear precipitin Scl 70 . Normal values included full blood count; erythrocyte sedimentation rate; $C$ reactive protein, urea, and electrolyte concentrations; creatinine clearance; and 24 hour urinary protein excretion. Penicillamine, colchicine, and stanozolol were ineffective, and in March 1982 pulse therapy with methylprednisolone and cyclophosphamide was instituted. After three doses she complained of cough and pleuritic chest pain. On examination she was found to be feverish $\left(38.4^{\circ} \mathrm{C}\right)$ and had a left sided pleural effusion. No sputum could be obtained, but blood cultures grew

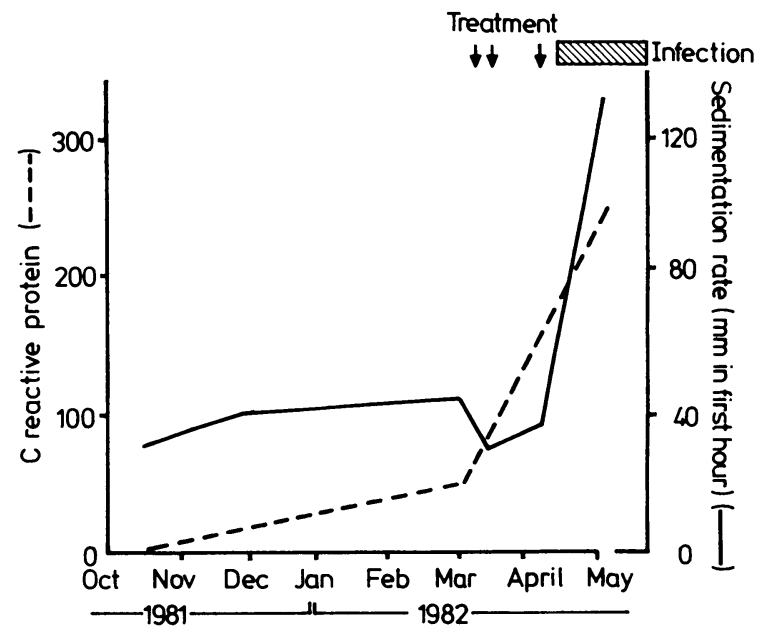

Changes in $\mathrm{C}$ reactive protein and erythrocyte sedimentation rate in response to disease activity, treatment, and infection. (Normal values: sedimentation rate less than $15 \mathrm{~mm}$ in first hour; $\mathrm{C}$ reactive protein less than $6 \mathrm{mg} / 1$.)

Staphylococcus aureus. Pleural fluid contained pus cells, glucose 6.6 $\mathrm{mmol} / 1(119 \mathrm{mg} / 100 \mathrm{ml})$, and protein $45 \mathrm{~g} / \mathrm{l}$, but cultures were sterile; pleural biopsy showed no evidence of tuberculosis. Erythrocyte sedimentation rate was $130 \mathrm{~mm}$ in the first hour, and the $\mathrm{C}$ reactive protein concentration was $250 \mathrm{mg} / 1$ (see figure). She responded to flucloxacillin and fusidic acid but later died in renal failure. Permission for necropsy was refused.

\section{Discussion}

The acute phase response was previously thought to be defective in scleroderma. Our patient with classic progressive systemic sclerosis also showed minimal acute phase response despite widespread active scleroderma but a pronounced rise in acute phase proteins in response to infection, changes in $C$ reactive protein concentration and erythrocyte sedimentation rate being similar to those in other patients with infection.

$C$ reactive protein is produced in the liver, probably in response to interleukin 1 released from macrophages stimulated by tissue damage. The ability of our patient to produce a normal acute phase response to infection strongly suggests that in 
progressive systemic sclerosis the liver is capable of producing acute phase proteins. In vitro studies of monocytes from patients with progressive systemic sclerosis have shown that when stimulated with lipopolysaccharide they are capable of producing interleukin $1 .{ }^{5}$ This suggests that infection, disease activity, and prostaglandin $E_{1}$ infusion have different mechanisms of producing an acute phase response, either at the level of macrophage stimulation or in the liver. Clearly further research is needed into the mechanisms of the acute phase response both in normal subjects and in patients with systemic lupus erythematosus and progressive systemic sclerosis.

\section{References}

1 Pepys MB. C reactive protein 50 years on. Lancet 1981 ;ii:653-7.

Amos RS, Constable TJ, Crockson RA, Crockson AP, McConkey B. Rheumatoid arthritis: relation of serum $C$ reactive protein and erythrocyte sedimentation rate. $B r$ Med f $1977 ;$ i: 195-7.

Becker $G$, Walderburger $M$, Hughes GRV, Pepys MB. Value of CRP measurement in investigation of fever in SLE. Ann Rheum Dis 1980;39:50-2.

4 Whicher J, Bell A, Unwin J, Martin M, Dieppe P. The prostaglandin acute phase response is defective in endotoxin tolerant mice and humans with scleroderma. response is defective in endotoxin tolerant mice and humans with scleroderma. protein response to tissue injury. Ann NY Acad Sci 1982;389:482-5.

5 Sandborg CI, Berman M, Andrews B, Friou GJ. Interleukin 1 production by mononuclear cells from patients with scleroderma syndromes. Arthritis Rheum 1983;28 (suppl): 113 .

(Accepted 20 fuly 1984)

\title{
BamH I polymorphism in the Chinese: its potential usefulness in prenatal diagnosis of $\beta$ thalassaemia
}

\author{
VIVIAN CHAN, N K LEUNG, T K CHAN, A GHOSH, Y W KAN, D TODD
}

\begin{abstract}
The prevalence of the BamH I site $3^{\prime}$ to the $\beta$ globin gene in Chinese people was determined in 123 normal subjects, 40 patients with heterozygous $\beta$ thalassaemia, and 25 patients with homozygous $\beta$ thalassaemia. The site was present in $71.1 \%$ and absent in $28.9 \%$ of the chromosomes carrying normal $\beta$ genes. All 25 patients with $\beta$ thalassaemia major had the site.

This BamH I polymorphism may be used for prenatal diagnosis in about $29 \%$ of the pregnancies at risk.
\end{abstract}

\section{Introduction}

One approach in the prenatal diagnosis of $\beta$ thalassaemia is linkage analysis of the abnormal gene with polymorphic restriction sites on the chromosome. ${ }^{1}{ }^{2} \mathrm{Kan}$ et al observed that in Sardinians the $\beta$ thalassaemia gene is always located on the chromosome carrying the BamH I polymorphic site $3^{\prime}$ to the $\beta$ globin gene, ${ }^{1}$ and so absence of this site would exclude a diagnosis of homozygous $\beta$ thalassaemia. In the present study we compared, in Chinese subjects, the prevalence of BamH I polymorphism in the normal population with that in patients

University Department of Medicine, Queen Mary Hospital, Hong Kong

VIVIAN CHAN, PHD, DIC, reader

T K CHAN, MD, FRCP, professor

D TODD, MD, FRCP, professor

Paediatric Unit A, Princess Margaret Hospital, Kowloon, Hong Kong

N K LEUNG, MB, MRCP, consultant

University Department of Obstetrics, Queen Mary Hospital, Hong Kong

A GHOSH, MB, MRCOG, lecturer

Howard Hughes Medical Institute Laboratory, Department of Medicine, University of California School of Medicine, San Francisco, USA

Y W KAN, DSC, FRS, professor

Correspondence to: Dr V Chan. with $\beta$ thalassaemia. We also attempted prenatal diagnosis of homozygous $\beta$ thalassaemia using this polymorphism in a couple at risk.

\section{Subjects, methods, and results}

All subjects studied were Chinese. DNA was extracted from white cells obtained from 123 normal subjects, 25 patients with homozygous $\beta$ thalassaemia, and 40 patients with heterozygous $\beta$ thalassaemia. In addition, fetal DNA was prepared from uncultured amniotic fluid cells $(20 \mathrm{ml})$ obtained from a pregnant woman at risk for homozygous $\beta$ thalassaemia at 17 weeks' gestation. The BamH I digested DNA fragments were hybridised with phosphorus-32 $\left({ }^{32} \mathrm{P}\right)$ labelled $\beta$ globin probe as described previously ${ }^{1}$ and the specific fragments identified after autoradiography.

When human DNA was restricted with BamH I and hybridised to ${ }^{32} \mathrm{P}$ labelled $\beta$ globin probe the $1.8 \mathrm{~kb} 5^{\prime}$ and $9.3 \mathrm{~kb} \mathrm{3}$ fragments of the $\beta$ gene were visible. In subjects in whom the $3^{\prime}$ BamH I restriction site was abolished a longer $3^{\prime}$ fragment of $22 \mathrm{~kb}$ resulted. The table shows the distribution of the BamH I fragments containing the $3^{\prime} \beta$ globin gene. The prevalences of the $9 \cdot 3$ and $22 \mathrm{~kb}$ fragments in the 123

Distribution of BamH I fragments containing the $3^{\prime} \beta$ globin gene in Chinese subjects

\begin{tabular}{lrccccccc}
\hline & & \multicolumn{2}{c}{ BamH I pattern } & & \multicolumn{2}{c}{ Prevalence } \\
& $\mathrm{n}$ & & $9 \cdot 3 / 9 \cdot 3$ & $9 \cdot 3 / 22$ & $22 / 22$ & & $9 \cdot 3 \mathrm{~kb}$ & $22 \mathrm{~kb}$ \\
\hline Normal subjects & 123 & 61 & 53 & 9 & & $0 \cdot 711$ & $0 \cdot 289$ \\
Heterozygous $\beta$ thalassaemia & 40 & 30 & 10 & 0 & & $0 \cdot 875$ & $0 \cdot 125$ \\
Homozygous $\beta$ thalassaemia & 25 & 25 & 0 & 0 & & $1 \cdot 000$ & 0 \\
\hline
\end{tabular}

Chinese subjects without $\beta$ thalassaemia were 0.711 and 0.289 respectively. In subjects with heterozygous $\beta$ thalassaemia the corresponding prevalences were 0.875 and $0 \cdot 125$. In contrast, all patients with homozygous $\beta$ thalassaemia had the $9 \cdot 3 / 9 \cdot 3 \mathrm{~kb}$ pattern.

In the family presenting for prenatal diagnosis the father had one chromosome carrying the $9.3 \mathrm{~kb} \beta$ thalassaemia gene and one containing the $22 \mathrm{~kb}$ normal $\beta$ gene. In the mother both chromosomes carried the $9.3 \mathrm{~kb}$ fragments. The family contained two children with homozygous $\beta$ thalassaemia, both of whom exhibited a $9 \cdot 3 / 9 \cdot 3 \mathrm{~kb}$ pattern. When the fetal DNA was mapped a $9 \cdot 3 / 9 \cdot 3 \mathrm{~kb}$ pattern was observed. This indicated that the fetus was not normal but did not allow us to distinguish accurately between $\beta$ thalassaemia trait and homozygous $\beta$ thalassaemia. The mother refused globin chain analysis of fetal blood for additional diagnosis and elected to have an abortion. 